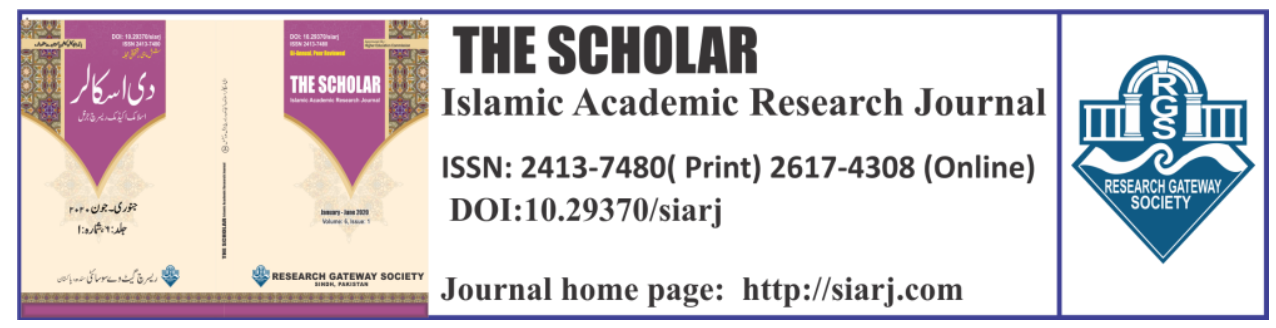

\title{
INTRODUCTION TO THE ENCYCLOPAEDIA OF ISLAM (A CRITICAL ANALYSIS OF THE ORIENTALIST APPROACH AND WESTERN SUPREMACY)
}

\section{Moosa Lakhani}

Research Scholar, Department of Comparative Religion And Islamic Culture University Of Sindh, Jamshoro.

Email: moosalakhani@gmail.com

ORCID ID:

https://orcid.org/0000-0002-3817-7675

\section{Mukhtiar Ahmed Kandharo}

Associate professor, Department of Comparative Religion and Islamic Culture at university of Sindh, Jamshoro.

Email: hafizmukhtiar@gmail.com

ORCID ID:

https://orcid.org/0000-0003-0194-7223

To cite this article:

Moosa Lakhani, Mukhtiar Ahmed Kandharo. "INTRODUCTION TO THE ENCYCLOPAEDIA OF ISLAM (A CRITICAL ANALYSIS OF THE ORIENTALIST APPROACH AND WESTERN SUPREMACY)" The Scholar-Islamic Academic Research Journal 6, No. 1 (May 31, 2020): 39-62.

To link to this article: https://doi.org/10.29370/siarj/issue10ar8

\begin{tabular}{|c|c|}
\hline Journal & $\begin{array}{l}\text { The Scholar Islamic Academic Research Journal } \\
\text { Vol. 6, No. } 1 \text { ||January -June } 2020 \text { || P. 39-62 } \\
\text { Research Gateway Society }\end{array}$ \\
\hline DOI: & 10.29370/siarj/issue10ar8 \\
\hline$\overline{\text { URL: }}$ & https://doi.org/10.29370/siari/issue10ar8 \\
\hline License: & Copyright c 2017 NC-SA 4.0 \\
\hline Journal homepage & www.siarj.com \\
\hline Published online: & $2020-05-31$ \\
\hline
\end{tabular}
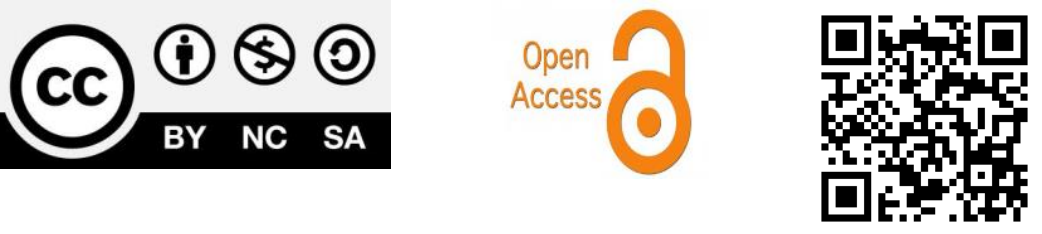
THE SCHOLAR (January- June 2020)

\title{
INTRODUCTION TO THE ENCYCLOPAEDIA OF ISLAM \\ (A CRITICAL ANALYSIS OF THE ORIENTALIST APPROACH AND WESTERN SUPREMACY)
}

\author{
Moosa Lakhani, Mukhtiar Ahmed Kandharo
}

\begin{abstract}
:
Orientalism is an idea originated in the west to define east and its forms of arts. It gained its strength from the Industrial west, which provided for necessary tangible and intangible investment necessary in furtherance of the idea from defining Europeans for not only east but also all nonEuropeans. The paper elaborates the nature of the first edition of the Encyclopedia of Islam (EI1) in the light of orientalism and explains how the west used it to create western supremacy. The paper also considers different aspects of the El1 to establish why and how it was an essential book for the western scholarship tilted towards Islam and how and why it was painted with objective and biased approach.
\end{abstract}

KEYWORDS: Orientalism, Encyclopedia, Islam

\section{INTRODUCTION:}

There has always been a clash of civilizations for as long as human race has existed. The grounds for these confrontations have always been changing with the passage of time. The most cited one is the Renaissance, which was taken as the revival of art, and according to some, it was art of revival for humanity in Europe. It started in Florence, Italy and soon reached across all parts of Europe. It was accompanied by explosion in excursions, marriages and diplomatic explorations. Firstly, it took out clergy and the church from the equation of success and replaced it with natural philosophers (scientists) and laboratory, also emphasized on the 
idea of attainment of knowledge through senses only and empirical methods of observations. It left no stone un-turned to deny the truth of theology and gave birth to empiricism.

As soon as Islam reached Europe, despite the fact that it was repulsed in so many ways (one of them the renaissance), it still made it through to the hearts of the common and the elite. Through centuries, it left an immeasurable impact on lifestyles, business dealings, legislations, and politics of the region. As the wave settled down, yet another adventure began to explore Islam in the light of contemporary thoughts and methodologies of empiricism. There is nothing wrong in being curious to reveal the fact that is hidden as man is curious by nature and has expressed it too many times in too many ways. This was his curiosity that led him to eat the 'forbidden fruit' and consequently brought him to the face of the earth. Alternatively, we can consider a poet, philosopher and scientist, Khayyam who calculated the length of a year to the most accurate value ever. Until then the man was tied to a concrete belief that not everything can be tried and tested on the man-made rules of science. Therefore, orientalists put Islam under the scientific microscope for several reasons.

\section{ORIENTALISM AND THE IDEA OF ENCYCLOPAEDIA OF ISLAM:}

Orient is a man-made idea; it was not there ever since. It is an idea that emerged and originated from the west in order to define east. It can also be put in a way that it actually helped explaining Europe in contrast to the east. As a hegemonic, British and French were able to dive into an idea, an idea which was more than just an idea but a reality - a reality that had lives, customs and histories attached to it. It is necessary to understand that orientalism is brute fact because it is an idea of the hegemony. The powerful and the wealthy always has dominated the ideas and transformed 
them into reality - even by force if necessary. The reality of a kind that has to be accepted by everyone, except for the powerful, author illustrates it in a way that elaborates it further that,

'There is very little consent to be found, for example, in the fact that Flau-bert's encounter with an Egyptian courtesan produced a widely influential model of the Oriental woman; she never spoke of herself, she never represented her emotions, presence, or history. He spoke for and represented her. He was foreign, comparatively wealthy, male, and these were historical facts of domination that allowed him not only to possess Kuchuk Hanem physically but to speak for her and tell his readers in what way she was "typically Oriental." My argument is that Flaubert's situation of strength in relation to Kuchuk Hanem was not an isolated instance. It fairly stands for the pattern of relative strength between East and West, and the discourse about the Orient that it enabled."

Therefore, such ideas gave birth to 'Orientalism' or 'orient', which defined and contrasted west from the east and became a formidable force in shaping visions of how each of the previously mentioned societies saw each other in terms of race, language, culture \& traditions, customs, legal philosophies, theological approaches and even trades and regimes.

Orientalism gained its strength from the Industrial west, which provided for necessary tangible and intangible investment necessary in furtherance

\footnotetext{
${ }^{1}$ Edward W. Said, Orientalism (London: Routledge \& Kegan Paul Ltd., 1978), 14.
} 
of the idea from defining Europeans from not only east but all nonEuropeans. It has been acclaimed by the history itself that orientalism depended on flexible positional superiority, which gave west the power to exercise the possible aspects of relationship with the orients without ever letting go of their own way of doing things. Since it was the hegemon, not just politically, but in other aspects pertaining to science, literature, and war and so on, therefore, not much resistance was seen from the side of the orients to the moves made. Conclusively, with the kind of hegemony as explained above and general knowledge about the orient, a new academic science emerged during and in the end of the eighteenth century, which the author has put beautifully in the following words,

\section{'there emerged a complex Orient suitable for study in the academy, for display in the museum, for reconstruction in the colonial office, for theoretical illustration in anthropological, biological, linguistic, racial, and historical theses about mankind and the universe, for instances of economic and sociological theories of development, revolution, cultural personality, national or religious character. ${ }^{2}$}

Though it started as an idea that was more related to an academic one, however, after the renaissance, west had new empirical standards of looking at the world societies and their citizens, and they measured practices of all sorts with new measurement techniques, therefore, they were more critical of the things that came by and were not of their

\footnotetext{
${ }^{2}$ Said, 15 .
} 
acceptability. Orient was not anything like them and in the beginning, it was more logical concerning matters like as to who or what the orient were? And later on it expanded to something else. There were two sides, on one hand there were original distinguished works of Silvestre de Sacy's Chrestomathie arabe or Edward William Lane's Account of the Manners and Customs of the Modern Egyptians, and on the other hand, there were Victorian pornographic novels like the lustful Turk or even Renan's and Gobineau's racial ideas. Renan believed that Semitic race is inferior to the Aryan race and they are have limited thinking capacity because of their dogmatism and that they are not able to conceptualize cosmopolitan civilization. He also added Semitic has to be an incomplete race. Gobineau was an elitist, who mastered the theory of master race for Aryans. He wrote a book titled, 'Essai sur l'inégalité des races humaines (An Essay on the Inequality of the Human Races), where he claimed that the aristocratic race is superior to commoners because they have never bred with the lower races. Such idea by this French author prevailed in the years following 1848.

The conclusion of the analyzation of the history of the emergence of this academic branch or Orientalism related to orients shows that the interest of the writers in this new aspect of study was not just based on logic but also as Said puts, is more horrifying, that it was not just the originality based on facts but there was also the amalgamation of emotions, sentiments, investments, and projection. The last word of Said arouses me, because with the projection the world only sees what is been projected, the reader only reads what is been written, the audience will never be able to experience the reality unless they are out of their comfortable beds.

The reality was never overshadowed, fortunately, the nature has blessed the eastern hemisphere with lot what the western hemisphere craves for - 


\section{Introduction to the Encyclopaedia of Islam}

spices. In the name of spices, expeditions travelled from Europe to India. After UK was declared champion in textiles, the wounds of the 'great fire' were not healed yet, and therefore, Amsterdam was looking forward to an opportunity through seas. As soon as they were able to mechanize the production of the sailing ships by cutting the logs through machines, they were able to produce in masses and were now the largest fleet travelling across the globe for trade. Indian sub-continent provided for enough spices to meet the craving at that time and capacity to produce more, and this marked the establishment of East India Companies.

\section{'The creation of the Bank of England in 1694 finally gave London a bank that could act on a scale as large as that of the Bank of Amsterdam. Unlike the Bank of Amsterdam, however, the Bank of England was a joint-stock company along the lines of the East India Company, Royal African Company and Hudson's Bay Company to name a few of the already existing companies, 3}

As can be deduced from the excerpt above, there were few major powers within the Europe and then smaller ones but together east to deal with all of them at once. It was not like that west was not familiar with the east but rather it was well aware because of the Muslim's conquest around the world. They were aware of the traditions, cultures and even awed with the architectural designs brought in by the Muslims. In addition to this, there was an ample introduction of the west with Muslims in the field of

\footnotetext{
${ }^{3}$ Ann M. Carlos and Larry Neal, "Amsterdam and London as Financial Centers in the Eighteenth Century," Financial History Review 18, no. 1 (2011): 31, https://doi.org/10.1017/S0968565010000338.
} 


\section{Introduction to the Encyclopaedia of Islam}

sciences; specially medicine, physics, astrology, astronomy, mathematics and so on. They knew this race has produced and brought up Avicennas, Khayyams, and Khawarizmis. West has always felt extra ordinary around Muslims and has taken advantage from latter's contributions.

Such articles and researches of the orientalists that follow the new methodology of scientific empiricist approach demand serious attention in terms of correction are compiled in Encyclopaedia of Islam (EI), published by Brill (in Leiden, Holland) under the patronage of the international union of academies. It has attracted students and scholars alike as a reference material for over a century now because not much has been written about Islam and compiled in such a way like Brill did.

To begin with, it is yet interesting and pertinent to mention that the word Encyclopaedia is taken from two greek words - enkyklios and paedia - the former translated into English as general or regular while the former translates as education, which is therefore understood as complete education. The interesting part as these two words were separate and were reduced to a single word due to a scribble error by a typist. The tradition is as old as two millennials and books have been written about this art of explaining and imparting knowledge. The art has evolved for good through centuries and have adapted to changes in nature, technology, authorship, readership, geographies, and much more.

A BROADER VIEW TOWARDS THE SIGNIFICANCE OF ENCYCLOPAEDIA OF ISLAM:

Before diving into the EI's history, it might also be important to know that around the time when the first edition was started, as I have explained earlier the political perspective and the approach of west towards east, there were several attempts on different theological Encyclopaedias. Therefore, EI was and also is one of its kind in the specific theological 


\section{Introduction to the Encyclopaedia of Islam}

perspective, but on the broader spectrum there were other Encyclopaedia Being worked upon not just related to Islam but other theological approaches around the world specifically Christianity.

Encyclopaedia Biblica: A Critical Dictionary of the Literary, Political and Religion History, the Archeology, Geography and Natural History of the Bible is a work of several notable literary theologians of the 19th century. The work is based on names and places encountered by user in Bible and its traditional Apocrypha. In addition to this, the old Catholic Encyclopaedia and also referred as original Catholic Encyclopaedia is a work comprising four volumes of which the first appeared in 1907 and the rest of the three in 1912. It explained to its readers in detail the doctrines and actions of Catholic Church and its believers. The work even continued after 1912 and master index was published later after years of the publishing of the three volumes and supplements continued afterwards in 1922 and 1958. The works on the update to the original Catholic Encyclopaedia was started in 1960 in coordination and collaboration of the Catholic university of America and McGraw-Hill book company. The new work was named as New Catholic Encyclopaedia of which we saw different editions, first one in 1967 and later the second edition in 2002. In addition to these Encyclopaedias, later when EI's second edition was in progress, the world saw another work of theological nature, based on Christianity, Theologische Realenzyklopädie - German Encyclopaedia of theology. The first edition was published in 1977 and the last one was in 2004. The purpose was to continue the tradition of generic Encyclopaedias but also to achieve ecumenism - building closer relationship and understanding among the Christians of different churches.

Apart from Christianity, works on Judaism also became prominent in the beginning of the 20th century. A notable published work comprising of 


\section{Introduction to the Encyclopaedia of Islam}

15000 articles and deemed as the 'the most monumental scientific work of modern times'. It was dubbed as The Jewish Encyclopaedia: A Descriptive Record of the History, Religion, Literature, and Customs of the Jewish People from the Earliest Times to the Present Day, published in 12 volumes between 1901 to 1906 in English.

19th century has been a century of numerous works based on the same theological nature and EI was one of them. It is important as it is the only fundamental reference work for Islam and below is a small glimpse into how the EI today came into the way it is today, it took a life time to produce and maintain such humungous work,

EI has three different editions. The EI's first edition (EI-1) was standardized on the Pauly-Wissowa model. The support was provided by the international union of academies under the coordination of Leiden University. The work was one of its kind, therefore, was published by Brill in Holland in four volumes, which later saw several supplements from 1913 to 1938 in English, German and French. The first one being printed between 1913 and 1938, which gave access to 9000 articles, in three different languages - English, French and German. In the first edition the remarkable struggle of Martijn Theodoor Houtsma and the fellow authors can be easily seen. The work of the first edition came to be known as The Encyclopædia of Islam: A Dictionary of the Geography, Ethnography and Biography of the Muhammadan Peoples. It included entries in Vol.1 from A-D, which was published in 1913. Afterwards in Vol.2, the articles chronologically from E-K were taken up and subsequently published in

\footnotetext{
${ }^{4}$ Jacob Rader Marcus, "THE LARGER TASK," in Ninetieth Ordination Exercises of the Hebrew Union College - Jewish Institute of Religion (Cincinnati, Ohio: The Jacob Rader Marcus Center of the American Jewish Archives, 1974), 8.
} 


\section{Introduction to the Encyclopaedia of Islam}

1927. The third Volume in the series (Vol.3) had included information about characters, geographies and also ethnographies like the first two between L-R that got published in 1934. Finally the last volume (Vol.4) included alphabetically sorted articles alike the first three between $\mathrm{S}$ and $\mathrm{Z}$ that got published in 1936. Furthermore, the five supplements were published in 1934, 1936, 1937(twice), and 1938. The French version of the EI-1got completed in 1938 and came be known in French as 'Encyclopédie de l'Islam: Dictionnaire géographique, ethnographique et biographique des peuples musulmans'. For about the German part, it came along like the other two languages (English and French) and was completed in between 1913 and 1938 and came be known in German as 'Enzyklopaedie des Islām: Geographisches, ethnographisches und biographisches Wörterbuch der muhammedanischen'.

A shorter version was later introduced to public in 1953 covering different topics mostly related to Islamic law and religion. It was a shorter abridged version therefore was recognized as Shorter Encyclopaedia of Islam (SEI). Some of the works of the latter Encyclopaedia were later translated into Urdu, Arabic and Turkish. The translations, as also expressed earlier, proved to be the foundation of independent scientific works at later stage since it demanded corrections and amendments which were also incorporated at later stages in EI itself.

Therefore, the translation in Arabic with its authors came be known as,

$$
\begin{aligned}
& \text { دائرة المعارف الإسلامية ، اصدر بالألمانية والإنجليزية والفرنسية واعتمد في الترجمة العربية }
\end{aligned}
$$

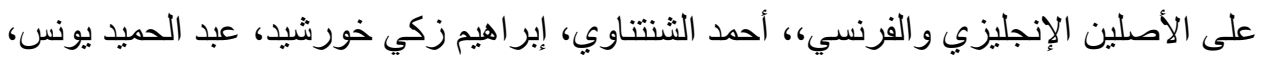

$$
\begin{aligned}
& \text { الطبعة r، القاهرة: دار الثعب، - '1969' } 1979 .
\end{aligned}
$$


The translation in Turkish was known as, M. Th. Houtsma et al. eds., İslâm Ansiklopedisi : İslâm âlemi coğrafya, etnografya ve biyografya lûgati, 13 in 15 vols., İstanbul: Maarif Matbaası, 1940-1988.

Lastly, the translation in Urdu was done by a team in Lahore, Pakistan, which took place between 1959 to 1993, and is known in Urdu as,

$$
\text { مختصر اردو دائره معارف اسلامي،، لاهور، دانشخاه ينجاب، محمود الحسن عارف }
$$

The works of translation in Urdu was started by University of Punjab in the 50s. Later the work came to a halt because of the lack of funds and the leader. Afterwards, the Asia foundation provided for the needed funds and therefore, the work was resumed and later 21 out of 25 volumes were published until 1985

(The work in EI-1 and SEI was mainly done by the European authors thus their perspective on Islam and its civilization.)

As soon as the SEI was published, in 1954, another work began on EI's second edition (EI-2) which went on for couple of decades; specifically from 1954 to 2005, (some of the indexes got published even in 2007). This edition of the EI was edited by P. J. Bearman, Th. Bianquis, C. E. Bosworth, E. van Donzel, W. P. Heinrichs et al., Encyclopædia of Islam, and 2nd Edition. 12 vols. with indexes, etc., Leiden: E. J. Brill, 19602005.

The drastic difference was that this time a lots of authors from the Islamic arena of middle-east and sub-continent participated by submitting their works. Therefore, the tone of the EI-2 was different from EI-1 and there was a drastic difference. The same problem persisted that since the work was spread on number of decades, it might not have continued the legacy that it reclaimed earlier, and was not definitely absolutely realistic in approach. As the author suggested that, 
'The persons do not represent the traditional learning of Qom and alAzhar, to be sure; they have been trained in Western-style universities, and they share the methodology if not always the cultural values and attitudes of their Western colleagues. Even so, the change in tone is perceptible and significant'. 5

The scope of third and the final edition of EI (EI-3) has been a little different in terms of topics approached. With the fast pace changing demographics, after 2007, it adapted to Muslims' movements and focused also on the Muslim minorities around the world. It gave due attention to expansion of Islam and its dominance in different societies around the globe. Though it was available online, printed parts were published four times a year after the considerable effort put in by sectional editors and chief editors. Its highlighting factor was wide-ranging treatment of Islam and relevant phenomenon around the globe in the 20th century.

Thus in the 20th century, EI's different editions did not only pave the way for other like Encyclopaedias but also contributed to fundamental reference work in the fields of geography, ethnography and biography of Muslims. The EI is considered as the standard reference work in the academic discipline of Islamic studies in the west, and there are several reasons for that, which are as follows,

\section{FOUR EDITIONS}

Hundreds of articles and research papers publish every year under the academic discipline of Islamic studies in the east and the west.

\footnotetext{
${ }^{5}$ R. Stephen Humphreys, Islamic History: A Framework for Inquiry (Princeton, New Jersey: Princeton University Press, 1991), 5.
} 
The Scholar Islamic Academic Research Journal

Vol. 6, No. 1 || January -June 2020 || P. 39-62

https://doi.org/10.29370/siarj/issue10ar8

Nevertheless, the significance of the EI doubles due to its regular updates.

There have been three different editions for it in the past century in 191338, 1960-2005, and 2007 (excluding a SEI which has been explained before). Keeping in mind the huge volume of work undertaken at the very first stage, it requires vigorous and determined attempt to bring a regular update to the EI. The updates do not only include the newly published pieces of research and articles, but it would also rectify the errors made in the previous publications. Such authors who revise are put in brackets in the list of 'Authors of Articles in this Volume' in the beginning of the Encyclopaedia. When the editorial committee updates an article, marks an asterisk on it to make it easier for the user/reader to understand that the article has been amended, and there are plenty of articles being amended every time a new update arrives. On the other hand, the amendments procedures also work where the works have been translated; the translator finds an error would rectify it in the translations. These errors are not rectified in the original text until the corroboration happens.

In my opinion, it is also important to mention, that the kind of errors made in EI can be generally divided into two categories. The first category consists of those ones, which are spelling errors and can be considered as the slip of the pen, and the second ones are those which were made based on the prejudicial approach of the authors. The latter is not the error, rather an intentional mistake to prove the point, regardless of deviation from the methodology, of which the examples will be provided in amplitude IA. Therefore, even with the situations like the ones happening above, handling thousands of articles, to put it them in order and update them is really a commendable job. 


\section{NUMEROUS TITLES}

EI definitely includes numerous titles related to Islamic history, towns, texts, personalities and so on. The light of Islam began to shine in Arabia but it reached all parts of the world slowly and gradually. Everyone who had visited Arabia at the time, believer or non-believer alike, was the carrier of the message brought to Prophet Muhammad upon whom be peace by Gabriel upon whom be peace. People from all lifestyles were able to grasp the simplicity of the religion and it was easiest for them carry it with them wherever they travelled afterwards. Being a student of Islamic history, I feel no hesitation in proclaiming that it was not only the rules of the war, but also the opportunities made available in the trade and grant of the fundamental rights that made it easier for the message to reach all corners of world. Islam is the only true message that did not only present the idea of fundamental rights but also gave detailed descriptions about contract laws, laws of private nature, laws of public interest and so on. It paved the way towards and granted social rights to men and women as per their societal needs. The rights of third and the fourth generation claimed by Europeans and Americans to be their innovation, rather existed and were implemented in detail at the time of the Prophet Muhammad upon whom be peace and even in the era of the rightly guided caliphs.

Since it was truth, thus, it was unstoppable. Therefore, when the authors penned down the topics in the chronological order, there was lot to write that also made sense. As according to the publisher, Ė.J.Brill, the EI includes, "articles on distinguished Muslims of every age and land, on tribes and dynasties, on the crafts and sciences, on political and religious institutions, on the geography, ethnography, flora and fauna of the various countries and on the history, topography and monuments of the major towns and cities. In its geographical and historical scope it encompasses 
the old Arabo-Islamic empire, the Islamic countries of Iran, Central Asia, the Indian sub-continent and Indonesia, the Ottoman Empire and all other Islamic countries". ${ }^{6}$ Still with the century has passed, EI seems to be requiring much more details and explanations. At several occasions, one find that there are literary pieces, despite their length and approach, demand serious attention once again to corroborate with history and facts. With the amount of topics covered in the Encyclopaedia, it becomes visible as to how far and wide is the reach of Islam and truly a divine religion that is a complete code of life,

$$
\begin{aligned}
& \text { 'And which of the favors of your lord will you } \\
& \text { deny?"7 }
\end{aligned}
$$

\section{RECOGNITION}

The work on the EI started in 1913 and numerous western philosophers, scientists and researchers submitted their pieces on the relevant topics of their expertise. A huge number of writers and authors contributing towards the completion of the EI, they ranged from different parts of the world, and wrote significantly on several topics. EI-1 and SEI were the examples of European mindset, where mostly the work was undertaken by the western authors. One would rarely find an article written by an eastern in the said editions. While for the last two, there were several writings by the easterners, to the point that one may easily find a relative writing. Still the authors from the east were trained in western style of thinking in order to stimulate the kind of writing necessary and required for the works

\footnotetext{
${ }^{6}$ P.J. Bearman et al., eds., The Encyclopedia of Islam (Second Edition), n.d.

${ }^{7}$ Holy Quran (Jeddah: Dar Abul Qasim Publishing House, n.d.), 55:37.
} 
produced earlier. This is to make user not feel the difference in the previous and new editions, still not successful.

However, it was able to collect and publish a large and comprehensive data collection, but the time span of about four decades made it impossible for them to keep track of the standardized methodologies of research, which keeps away from biased approach, as the author writes and I quote again,

'They have been trained in Western-style universities, and they share the methodology if not always the cultural values and attitudes of their Western colleagues, ${ }^{8}$

Therefore, until the masses had realized this, it had gained popularity. Despite the fact that it has numerous entries, it comprises of an indispensable list of contents in the alphabetical order, to easily access the content in the vast voluminous work. The recent publication is available in nine (9) volumes with dimensions 7 x 12.2 x 10 inches.

\section{POLYGLOT:}

The widespread use of the EI demanded it to be readily available to researchers and masses alike without the obstruction of language. Therefore, the availability of EI in international languages like English, French and German made it possible for the people of different regions of the west to be open to the work.

In addition to this, translations into Urdu, Arabic and Turkish had made it possible for people of subcontinent, middle-east and turkey to be informed

\footnotetext{
${ }^{8}$ Humphreys, Islamic History: A Framework for Inquiry, 5.
} 
The Scholar Islamic Academic Research Journal

Vol. 6, No. 1 || January -June 2020 || P. 39-62

https://doi.org/10.29370/siarj/issue10ar8

about this work of orientalist as well. This had sparked the notion in two ways. The first one was in favor, people who had been trained in the western style of thinking started writing for EI, keeping themselves neutral most of the times. The controversially in the articles were found mainly in the non-muslim contributions. For example, the contribution by Abdul Hai from University of Dhaka was about Bengali in terms of it being the Muslim language or being the literature. Another contribution from Tunis was by Abdul Wahab who contributed towards Abbasiya (the tribe). Therefore, their contributions and writings helped continue the pace of the work as before keeping in reference the primary sources for consultation. On the other hand, the other notion was not mostly in favor, as it deviated the kind of approach already being set up for the readers previously in EI1 and SEI, the latter also got translated into three languages mostly spoken by muslims around the world. Therefore, it was hard to keep up the set tone and the change was significant in the scholarly circles.

Therefore, in the light of the above-mentioned reasons, it can be easily concluded that EI became an important source for researchers and masses in the west who wanted to study Islam and were not able to do so because the primary sources were in Arabic and they were not conversant with it. In addition to this, it was not just because of the un-availability of the any other equivalent source, but also because there was no language barrier, as well as, it was a comprehensive work by those western scientists and philosophers, which are regarded experts in their respective fields in the west.

\section{BIASED APPROACH}

Therefore, Orientalists have always regarded the Islamic history as an important aspect of their study. The perspective of the earliest orientalists about different personalities and events from the Islamic history was more 
The Scholar Islamic Academic Research Journal

Vol. 6, No. 1 || January -June 2020 || P. 39-62

https://doi.org/10.29370/siarj/issue10ar8

prejudicial than objective. On the other hand, the modern orientalists, who try to sound more scientific, but due to lack of understanding of the Arabic and reliance on weak narrations have made it impossible for them to show true and accurate depiction of the Islamic history. The deliberate rejection of the reliable historical resources is also the result of prejudice.

Therefore, the adoption of objective and biased approach was the result of establishing following superiorities.

\section{POLITICAL:}

It is the period between 14th and the 17th century when the world witnessed widespread cultural, artistic and political change in Europe and regime change around the world. It was the time when princes and monarchs were expanding their sovereignties around the world through their trade caravans, armies and establishment of bureaucracies. In the process, they created nation states and this lasted until World War I (Huntington). This was the time when Europe getting lost of its control over the territories politically and it was the time when the works for EI started. The loss of political control would mean that together it was bring closer to the collapse of economy, law \& order, and beginning of the chaos. The experts believe that the systematic collapse can lead to a financial center to be not one anymore. It needs to have a complete institutional set up in order to survive at length. Therefore, business historians are of the view that,

\footnotetext{
'The precise composition of institutions and markets in each center's financial system usually varies with predictable consequences for the extent and depth of its
} 
The Scholar Islamic Academic Research Journal

Vol. 6, No. 1 || January -June 2020 || P. 39-62

https://doi.org/10.29370/siarj/issue10ar8

corresponding network of financial ties, which in turn

determine the dominance and persistence of the center. ${ }^{9}$

These institutions and humungous flow of wealth that show power, which is the first essential in the Foucault's theory of power and knowledge. To subjugate completely, the second component of knowledge was the most important one and therefore, it was totally worked upon. According to Foucault's work, it can be understood that power is based on knowledge and makes use of knowledge; on the other hand, power reproduces knowledge by shaping it in accordance with its anonymous intentions. Therefore, he mentions and I quote,

$$
\begin{aligned}
& \text { 'Indeed, itis in discourse that power and knowledge are } \\
& \text { joined together. And for this very reason, we must } \\
& \text { conceive discourse as a series of discontinuous segments } \\
& \text { whose tactical function is neither uniform nor stable. To } \\
& \text { be more precise, we must not imagine a world of } \\
& \text { discourse divided between accepted discourse and } \\
& \text { excluded discourse, or between the dominant discourse } \\
& \text { and the dominated one; but as a multiplicity of discursive } \\
& \text { elements that can come into play in various strategies.' }
\end{aligned}
$$

With the growing power and reproductions of knowledge, new fields are produced, enlarges the capacity to influence larger numbers of fields and create new ones subsequently. This continuous process is hard to slow

\footnotetext{
${ }^{9}$ Carlos and Neal, "Amsterdam and London as Financial Centers in the Eighteenth Century," 22.

${ }^{10}$ Foucault Michel, The History of Sexuality, Pantheon Books, vol. 1 (New York, 2007), 105.
} 
down let alone stop. When the power reproduces knowledge, the latter does not remain neutral as it will determine force relations. With the passage of time, the term knowledge has also been used as 'information', where big data corporations play an important role in the distribution of ideas and creating mindsets. One of the important sources is, thus, Encyclopaedias, now also available in digital forms. According to a recent research, Volume and control model has tried to explain how this information (previously known as knowledge) is used to turn big corporations into economic powers. ${ }^{11}$ Thus, power has always remained central, to stimulate political strength through economic or vice-versa.

In the political context, orient is also an object of power and subject of dominance. Thus, to establish that the current political system is best for the world for centuries to come, and the divine political approach is rather obsolete, an objective and biased approach towards orient approach was adopted in EI to create mindsets that approve of this.

RELIGIOUS:

Religious triumphalism or triumphalism is the notion that explains according to Merriam webster,

\section{'smug or boastful pride in the success or dominance of one's nation or ideology over others'.}

Religious triumphalism has become part and parcel of the church after it was used by the Second Vatican Council quite a number of times and then

11 Elad Segev, "Volume and Control: The Transition from Information to Power," Journal of Multicultural

Discourses 14, no. 3 (2019): 240-57. 
The Scholar Islamic Academic Research Journal

Vol. 6, No. 1 || January -June 2020 || P. 39-62

https://doi.org/10.29370/siarj/issue10ar8

picked up by the religious writers lately. ${ }^{12}$ Interestingly, this is no mere coincidence that the second Vatican council is supposed to take care of the relations between Catholic church and the modern world, with the use of such terminologies, a clear message is broadcasted is sent throughout the world.

Historically, it is related to Prophet Jesus' peace be upon him entry into the city of Jerusalem, according to the gospels (according to the research conducted by the Indian theologian V.Mariadasan in 1977). In addition to this, the idea also get its roots from the Roman Empire's idea of Triumph, which was legal, and public (related to state). No private person in his private capacity was able to conclude triumph. There were different forms of triumph, military and even religious triumph. The former was related to number of people wiped out, 5000, with a decisive victory, the latter was raising to the rank of immortal due to sacrifice for the capitol or the temple. ${ }^{13}$ Roman Empire or Rome being the center had definitely influenced Europe and the religious ideas of Christianity, which brought them to the idea of Triumphalism for themselves exclusively. As I mentioned earlier, as soon as the speakers at the Second Vatican council proclaimed or started to use the words, the idea spread quickly and was picked up the authors and researchers of religion.

Therefore, another factor that forced them to be unfair with the presentations and conclusions of Islamic historical facts was to create illusionary religious superiority. Since the majority of the writers in EI-1 and SEI were non-Muslims (as explained earlier in detail), it was not

\footnotetext{
${ }^{12}$ W. A. Visser't Hooft, "Triumphalism in the Gospels," Scottish Journal of Theology 38, no. 4 (1985): 491, https://doi.org/10.1017/S0036930600030301.

${ }^{13}$ Visser't Hooft, 495.
} 
The Scholar Islamic Academic Research Journal

Vol. 6, No. 1 || January -June 2020 || P. 39-62

https://doi.org/10.29370/siarj/issue10ar8

possible from them to applaud the relevancy of Islam even today. However, they principally mentioned to be partial and not favor any one side to have an un-biased approach, but it was difficult for them to do so.

\section{ACADEMIC:}

The house of Wisdom in Baghdad belongs to the era of the flourishing golden age of Muslims Ummah, when Muslims were developing culturally, scientifically and economically. It was the time when the knowledge of the world was translated into Arabic and Persian, under the scholarship around the world and leadership of Abbasid Caliph Harun alRashid. With the ample amount of Greek philosophical ideas at hand and various injunctions of the Quran and Hadith persuading to understand, ponder upon and evaluate the nature and phenomenon around, Muslims scientist from the Arab and Persian world dived into this deep sea of knowledge. The result was phenomenal that changed the world for good. The results were far reaching as the world can even the witness innovations based on the ideas promulgated then. The works of Fakhr alDin al-Razi on Islamic cosmology, rejection of the Aristotelian idea of earth being the center, even the notion of more than one worlds or universes based on the verse of Quran,

\section{'All praise belongs to God, Lord of the Worlds'14}

Another important figure, Al-Ghazali, contributed to the idea of earth's rotation, and the use of medicine, encouraged the use of anatomy

\footnotetext{
${ }^{14}$ Holy Quran, 1:1.
} 
The Scholar Islamic Academic Research Journal

Vol. 6, No. 1 || January -June 2020 || P. 39-62

https://doi.org/10.29370/siarj/issue10ar8

and idea of dissection based on the injunction of the Prophet Muhammad may peace be upon him in Sahih Bukhari,

'There is no disease that God has created, except that He also has created its treatment. ${ }^{, 15}$

Al-Khwarizmi's approach towards the solution of the problems led to several monumental academic fields, such as the field of algebra to explain and solve the law of inheritance in Islam and even several other fields like spherical trigonometry to find out the direction of Qibla.

The interaction of the west as a hegemon in the Muslims world at the time of the downfall of the Muslim's Mughal empire in the subcontinent, and Ottoman in present day Turkey gave chance to infiltrate Muslims world with the new ideas that divided them badly and took them away from the beautiful fusion of religion and science. ${ }^{16}$

With such a downfall of the Muslims around the world, psychologically it was natural for the contributors of the EI to show their command over the languages and grip over the subject. It was easy for them to access territories around the world and get advantage over the academic elite. Therefore, the understanding of the 'previous authors' on the subject were mostly irrelevant to them. The fact that they molded the already done researches in the name of methodologies and scientific approaches gave them undue advantage.

\footnotetext{
${ }^{15}$ Muhammab bin Ismail Bukhari, Sahih Al-Bukhari, ed. Mika'il Al-Almany, 1st ed., 2001.

${ }^{16}$ Mehdi Gulshani, "Can Science Dispence with Religion?," accessed January 10, 2020, https://www.al-islam.org/can-science-dispense-religion-dr-mehdi-golshani/can-sciencedispense-religion.
} 
The Scholar Islamic Academic Research Journal

Vol. 6, No. 1 || January -June 2020 || P. 39-62

https://doi.org/10.29370/siarj/issue10ar8

\section{CONCLUSION:}

It is indeed the matter of appreciation that the western scholarship is interested in making attempts to understand the historical and the intellectual knowledge of Islam and how it has impacted the world. However, it is also evident from the works, especially in the EI1, despite having defined rules it is difficult to reach an agenda and un-natural objective even under the light of orientalism without having to deviate from the primary sources. The paper conclusively explained why there had been enormous endeavors to subjugate the ideas mostly.

\section{(1)(0)}

BY NC SA This work is licensed under a Creative Commons

Attribution-NonCommercial-ShareAlike 4.0 International (CC BY-NC-SA 4.0) 